UDK 528.931.2

\title{
TRACKING VIOLATIONS IN VISUAL RESOURCES IN THE LANDSCAPE OF ASVEJA REGIONAL PARK
}

\author{
Jelena VAITKEVIČIENE் ${ }^{1}$, Aušra KUMETAITIENE் $\dot{2}^{2}$ \\ ${ }^{1}$ National Center of Remote Sensing and Geoinformatics "GIS-Centras", Sèliu g. 66, \\ LT-08109 Vilnius, Lithuania \\ ${ }^{2}$ Department of Geodesy and Cadastre, Faculty of Environmental Engineering, \\ Vilnius Gediminas Technical University, Sauletekio al. 11, Vilnius, Lithuania
}

E-mail: 2ausra.kumetaitiene@sumin.lt (corresponding author)

Received 28 October 2014; accepted 9 March 2015

\begin{abstract}
Research on landscape stability of regional parks, the status and conditions of the objects and attributes of natural and cultural heritage serve a significant contribution to the survey of the properties of the national heritage possessed in the preserved areas of the Republic of Lithuania. The objective of this article is the analysis of visual landscape resources of Asveja Regional Park in terms of the current state and conditions, changes and modifications within territorial sites as well as with regard to the accumulation and concentration of the objects, their scope and extent. It is possible to assess the efficiency and expediency of an environmental impact taking into consideration research observations. The area of Asveja Regional Park significant for an intense anthropogenic environmental impact and defined in monitoring data sheets and records of Asveja Regional Park referring to 2005-2010 has been selected. Monitoring has been carried out by the Authority of Asveja Regional Park according to the Lithuanian State Environmental Monitoring Program. In order to solve the conflict between society and the environment, the project preconditioned by the use of natural resources and the preservation of valuable objects has been developed. Study on landscape monitoring has been carried out at the local level. It has been fixed within the selected territories, namely, standardised reference sites chosen on the basis of the geosystem and targeted on geophysical-geochemical sensitivity and technogenization with preference for the analysis of the most vulnerable geopotencial territories, i.e. nature reservations, protected areas, shores and the coastlines of lakes providing a wide range of recreational potential. Natural and cultural heritage objects violating regulations on requirements for landscape preservation have been observed in the determined standardized areas as visual resources of the regional park landscape. In order to determine the territorial dispersion of the infringements of requirements for landscape protection, the authors have performed a spatial distribution analysis of visual observation targets calculating nuclear or kernel density. Weight points of requirements for the items violating landscape protection have been attributed thus considering the monetary value of the prescribed fines (following regulations on the specific type of the caused damage). The analysis of the study on specified spatial distribution has been accomplished involving some groups of objects violating requirements for landscape protection. Within the conducted research, the authors investigated the targets that violated requirements for landscape protection and made use of the recorded data. The available findings derive a conclusion that a major part of infringements are considered as recreation violations (40\%); violations in usage, trespassing, visiting forests and woodlands (5\%) comprise a minor part. In general, the greatest accumulation of infringements are determined to be located in the western and south-eastern part of Asveja Regional Park where their intensity exceeds more than 6 times the concentration of infringements in other investigated areas and territories.
\end{abstract}

Keywords: cultural heritage, natural heritage, spatial distribution, landscape, visual resources.

\section{Introduction}

The landscape is a sensitive territorial easy vulnerable formation reacting to changes in the environment and human interference, particularly in the territories where the activities of population are restricted or completely forbidden. Land reform started in 1990 greatly influenced the Lithuanian landscape. The preconditions resulting in land usage transformations 
cover the restitution of private land ownership, issues about the size of land plot, the problems of changes in land use and an increasing demand for recreational areas. The article analyses the landscape of Asveja Regional Park that signifies itself by a noticeable increase in its attendance and intensification of recreational potential, i.e. an evident anthropogenic impact on the environment. Asveja Regional Park is located not far from Vilnius, which influences the possibilities of attendance. Besides, local, regional roads and highways are also conveniently located. Despite the fact that there is a shortage of campsites, an increasing number of visitors and frequent attendance of the park are registered. The geomorphic characteristics of lakes, the coastline of Asveja Lake in particular (the total area of campsites and resorts amounts to about $30 \mathrm{ha}$ ), provoke the intensification of visitors. The numerous places of interests attract visitors; moreover, there are a huge number of picturesque valleys with rather transparent ponds and lakes located in them the majority of which are included in the list containing information on the conservation of cultural heritage relics. The landscape of Asveja Regional Park distinguishes itself by a variety and mosaic formations of hills, valleys, lakes, streams, gullies, biotopes and other elements of the landscape, especially in the western part of the park. The eastern part of the park, on the contrary, is monotonous concerning the landscape; as regards recreational activities, they are not popular. Within the boundaries of Asveja Regional Park, ten reserves and one reservation are located, the total area of which comprises $50,4 \%$ of the overall area of the park.

Even up to nowadays, Lithuania has never carried out systematic observations regarding the determination of landscape conditions, which could have accumulated the latest information available in this field as well as could possibly have assessed the efficiency and expediency of environmental activities. Information on the landscape, the Earth's Crust and land use has never been accumulated at regional and local levels. Any information regarding the internal aspects of changes in the ecosystem that could assist extensive analysis and might forecast the transformation of the landscape has never been available (DRL 2005).

\section{The subject matter and methodology}

Asveja Regional Park is a preserved area established by Resolution No. I-2913 'On the Establishment of Regional Parks and Reservations' (Žinios 1992) issued by the Supreme Council of the Republic of Lithuania or
Restitution Seimas on 24 September 1992 and agreeing on the preservation of Asveja Lake landscape, its natural ecosystem and cultural heritage properties. The article presents the analysis of the stability of the visual resources of the landscape of Asveja Regional Park, its current conditions and the prevailing situation considering available data on monitoring Asveja Regional Park and talks about the subject matter dated 2005-2010. The landscape of Asveja Regional Park is complex, and therefore difficulties in selecting impartial criteria that could unambiguously assist in assessing conditions for visual resources and revealing the causality of transformation have been encountered. In general, the problem of landscape monitoring, in the majority of European countries, is an inadequately solved issue (Pileckas 2004), and thus landscape analysis on cartographic representations have been also performed (Beconytė, Kryžanauskas, 2010). Lithuania has carried out research only on the impact of attendance loads for the landscape. Hence, the data presented in the article concern available assessment records in terms of tracking and observations of stable and variable characteristics of visual landscape recourses. To the present, neither observations nor assessments on the subject-matter or objectives of research studies have been performed in Lithuania so far (Laukaityte 2009).

The objective of the article is to assess the state and conditions of regular and variable visual resources of the landscape, including their transformation. The research study conducted by the authors has used monitoring observations and experimental tracking of regular national and cultural heritage targets from the point of view of their position. The visual resources of the landscape located in the territory of the park are from the records dated within the period from 2005 to 2010 (further called regular visual resources). The analysed visual resources are unpredictable, variable in time and space structures, comprise neglected, desolate buildings and have undergone infringements and violations in requirements for landscape protection and preservation regulations. Besides, recourses include cleared spaces after felling in forests, various vegetation stands, blocking up or interrupting the panoramic view of valuable cultural and aesthetic objects to be preserved and cleared spaces of the stands to be renewed. The authors have observed the new evident formation of the relief, especially of natural slopes and coastlines of the lakes, violations in the forms, shapes, sizes, distances, norms and standards of allowable and recommended structures and buildings. The authors followed the prescribed 
Regulations on the Environment of the Preserved Territories and the Breaching of the Rules and Regional Architectural Regulations on the Norms and Standards of Buildings in the Preserved Areas. Besides, the study included the observations of damage caused to objects and attributes not adopted for the attendance of visitors as well as harm caused to the territory (variable visual resources).

During the research study, regular visual recourses of the landscape have been investigated in the selected territories, the priority has been given to the territories of the most sensitive potential, namely to reservations and reserves, coasts of the lakes intended for recreational activities. The article analyses the situation of undergone transformations of regular visual resources of the landscape within the period of five years and points out the causes of these changes. Variable visual resources have been analysed in the total territory of the Regional Park from the point of view of their frequency, territorial distribution, scope and type. One reserve of the analysed territories of Asveja Regional Park has been included into the list, which specifies itself by the attempts made to preserve mature oak woods located in the peninsula of Asveja Lake and Žalktynè Lagoon. The intention was to preserve and make it serve as a standard of vegetation in Lithuania as well as a brooding place for rare birds to settle (7). The territory of Asveja Regional Park includes ten reservations where the activities of a man are limited to the ability to carry out scientific research, protect and increase the development of natural environmental resources as well as use the sites for educational purposes.

The objects of natural heritage (NHO) are natural objects possessing a scientific, historical and aesthetic value. There is a great number of valuable $\mathrm{NHO}$ and cultural heritage objects $(\mathrm{CHO})$ included in the Governmental list of the National Heritage Fund in the territory of the park. The list comprises the most valuable natural and cultural heritage sites having national significance and value and has been approved by the Resolution of the Government of the Republic of Lithuania. The territory under investigation has included nineteen archaeological and urban targets of cultural heritage, one geological reserve and five botanical NHO, namely Beržos Oak and Purviniškių Pine (2009) that have been excluded from the Governmental list. During the monitoring period of 2005-2010 in Asveja Regional Park, 82 violations in requirements for landscape protection have been registered. The research study has analysed and assessed their distribution, scope and accumulation within the territory.
To characterize the state and conditions of regular visual resources of $\mathrm{NHO}$ and $\mathrm{CHO}$, they are divided into three categories, namely high, intermediate and low. When the state 'low' is indicated, it means the state of an object is to be very similar to that when the object tends to disappear, decays or collapses or when the circumstances require overhaul renovation.

All variable visual resources exhibiting infringements on requirements for landscape preservation and conservation have been classified into forests and woodlands for usage and attendance, waters or water reservoirs, landscape and areas breaching constructional and recreational regulations. To the infringements of forests and woodlands for usage and attendance, have been attributed illegally cleared spaces and the cutting of trees, the other vegetation damage in the water areas or reservoirs, in the protection zones or on the slopes of lakes - the cutting of the vegetation zones, which is restricted there for constructional purposes. The research study has not recorded any illegal felling or clearing spaces in the other parts of Asveja Regional Park. Among infringements regarding the group of water reservoirs and water areas, violations in regulations on fishing, the improper usage of water scooters in the prohibited areas, parking and washing cars in the protected zones of water reservoirs have been recorded. The group of violations has covered damage caused to the forms of the terrain, namely flattening the relief, excavation of ponds done without the issued permits, illegally erected buildings or constructions that have been unused, abundant or left without owners, fenced shores of lakes and structures disfiguring the surrounding environment and local landscape. Among infringements on constructional regulations, violations disregarding standardized structural measurements, sizes, shapes or the illegal construction of structures and regional architectural regulations applied in the preserved territories have been recorded. As for infringements in terms of recreational activities, a visually perceived impact of visitors onto the landscape in the most vulnerable places of its territory has been attached. Recreational violations have been registered only in the standardized territories of Nikajos and Baluošai Lakes as well as Asveja Lake in Žalktynè Lagoon. Intermediate infringements have been recorded at $\mathrm{Ba}$ luošai Lake only; however, an insignificant number of these infringements have been recorded in other standardised territories.

Generally, the analysis of four groups of variable visual resources (infringements on requirements for landscape protection) has been made along with 
examining several groups of forest / woodland use and infringements on attendance, some groups of infringements on water areas and reservoirs and some groups of infringements on regulations on landscape construction. The findings of the conducted research study have been acquired by means of a spatial distribution analysis of the objects of visual tracking thus making it possible to determine territorial dispersion and then to select the method of calculation. By using Kernel Density calculations and applying data obtained from the set of points used in monitoring, the equivalent surface the values that depend on the accumulation of the points of the sites of the investigated field have been combined (Antrop, 1988; Sevenant, Antrop 2007; Silverman 1998). This method of calculation has been selected in order to be able to determine locations where infringements concerning requirements for landscape protection appear to be in abundance. By applying the above mentioned calculation method, Nearest Neighbour Analysis has been carried out. The Euclid distances have been measured from a particular site of a location of the observed objects up to the 'nearest neighbours' thus calculating the average of the distances to the 'nearest neighbours' of the objects with all set available data that later have been compared with theoretical average distance (Clark, Evans 1954).

The calculation process comprised three stages. The first one included covering by means of a fine rectangular grid of the totally analysed domain. The cell of the grid is - 50/50. During the second stage, the values of the density function taking into account each cell of the analysed domain were calculated thus determining the central position of each cell, namely the centroid, around which, the circle of the determined beam radius was drawn, i.e. the width of the band of calculating nuclear density. The deeper an object gets into the width of the band, the higher is the density value of the cell. The selected width of the band is $1500 \mathrm{~km}^{2}$. When calculating density, different weights are prescribed to the objects. Due to the fact that the weight of the object depends on the distance from it to the centroid, the weight of the objects located closer to the centroid is higher. Therefore, input into the final density value of the cell is proportionally higher. For the objects of $\mathrm{NHO}$ and $\mathrm{CHO}$, in accordance with their state or condition, the following weight points have been attributed: for a low state or condition -3 weight points to the objects, for an intermediate condition - 2 weight points and for a high condition 1 weight point have been attributed. As regards the objects violating requirements for landscape protection, weight points, in accordance with the monetary value of the fine (for particular violation in accordance with the prescribed fine) have been attributed.

\section{Findings of the research study}

The investigated regular visual objects in Asveja Regional Park are unevenly distributed (Fig. 1). The majority of them are located in the inaccessible sites of the park or places not adapted for visiting them. Therefore, the majority of the objects do not receive any impact of man's economic activity on the environment. Nearly a half of tracked NHO have indicated "high condition", one object has an "intermediate condition" and two objects have "low condition" (dead trees). During the period of tracking, no special transformations of the state or conditions among natural and cultural heritage targets have been recorded. The conditions and state of other objects have not been transformed, except for two rare cases when Purviniškių Pine (a former NHO) and Beržos Oak have withered; then, the latter one have been excluded from the list of the State preserved natural heritage objects in 2009. Therefore, at present, conditions are considered relatively high and, in the coming years, works regarding the adaptation of the objects for their attendance will have to be intensified. The above mentioned situation has been determined due to a favourable geographical location of targets, the restricted scope of constructional work in the area and the absence of large-scale industrial or farming enterprises. A greater majority of $\mathrm{CHO}$ have intermediate conditions (LRL 1993).

Four objects of cultural heritage are in high condition. The architectural targets or $\mathrm{CHO}$ most often are of high or intermediate condition. They are mounds, barrows but with an exception of Dubingiai School, the condition of this fixed cultural heritage object is low. The geographical location and the environment determine a relatively high or intermediate state or condition of $\mathrm{CHO}$. They are located in forested and hilly territories and do not have good-quality access roads. Besides, they are less sensitive to a physical impact.

During the research study, recreational infringements have also been tracked and registered, and violations in the usage of forests and in the attendance of visitors have been registered as the least in number. The percentage expression is very similar to infringements on water reservoirs and areas, violations in constructional regulations and the landscape.

The accumulation of variable visual objects and territorial distribution has been analysed in the four previously mentioned groups of landscape 


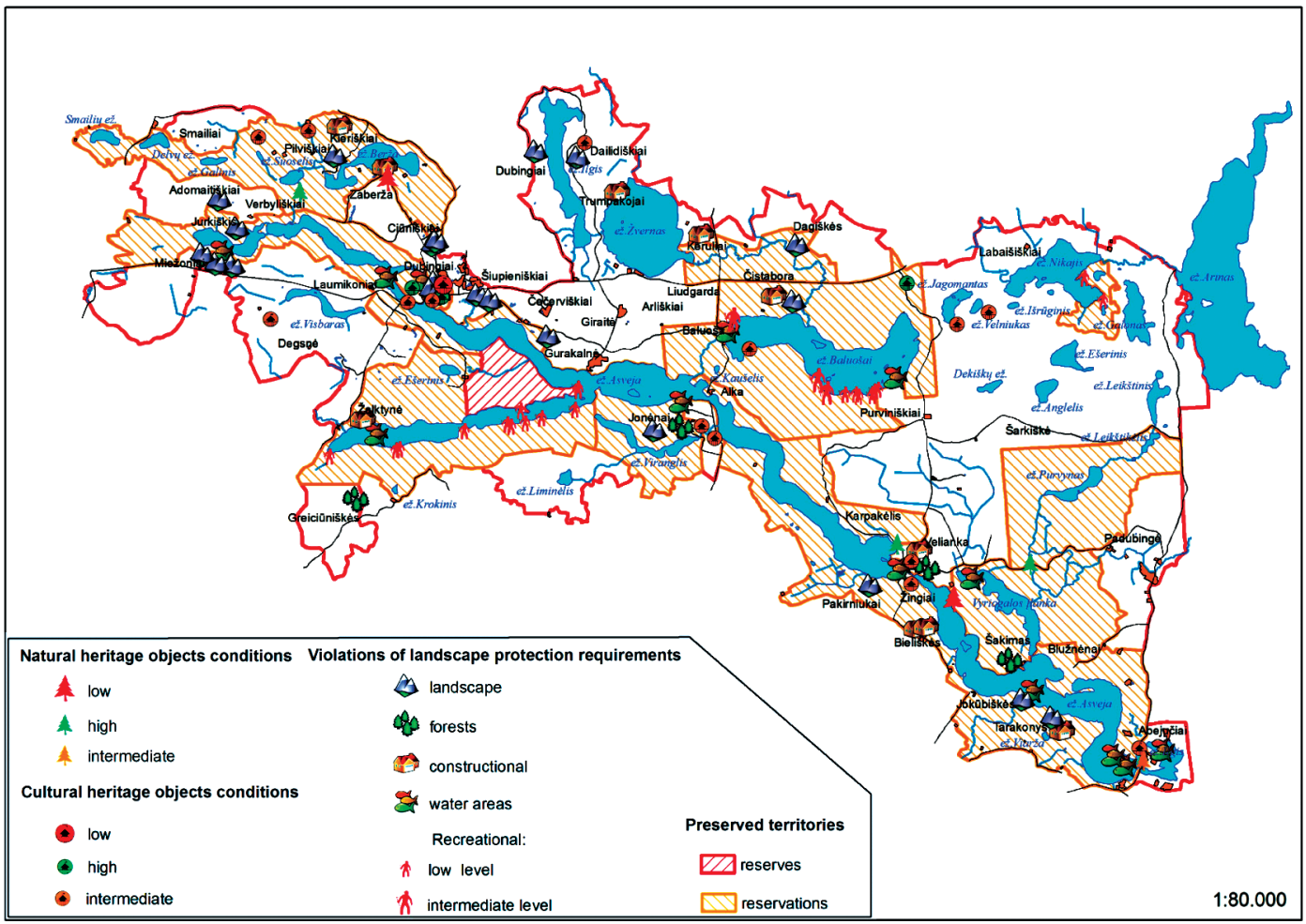

Fig. 1. Territorial distribution of violations in Asveja Regional Park

infringements. The aspect of a particular fine monetary value has determined the weight in these groups. The infringements on which the fine is of a low monetary value comprise $54 \%$ from the total number of groups. The average monetary value for fines comprised 33\% of violations and $13 \%$ of those comprised a large monetary value for fines. As for the first group of fines, infringements on landscape regulations prevail, infringements on the landscape make $42 \%$ and violations in construction regulation comprise $31 \%$. Infringements on water reservoirs and areas as well as violations in forest attendance make $19 \%$ and $8 \%$ respectively. Infringements on water reservoirs and areas (44\%) and landscape violations (42\%) prevail in the second group of fines. Infringements on forest attendance embrace $12 \%$, and violations in constructional regulations make $13 \%$. The third group of infringements contain only landscape violations that cover $83 \%$ and those of water reservoirs and water areas encompass $17 \%$.

The above mentioned infringements dealing with variable visual resources of the landscape, forest usage and attendance, water areas and reservoirs, landscape, construction regulations on landscape protection have been mainly recorded in three centres: in the western part of the park, between Dubingiai town, Berža and Asveja Lakes, in the south eastern part of the park and in the central part of the park at the shores of Asveja and Ilgio Lakes as well as at the central part of the park between Asveja and Baluošai Lakes (Fig. 2).

From the point of view of the landscape, the central and north-eastern parts of the park are more monotonous and less attractive for recreational activities or construction purposes. Meanwhile, the western and southern parts of the park distinguish themselves for a greater variety in the relief, ecosystems and biotopes of urban territories as well as other elements of the landscape, which increases the risk of the territory from the point of view of the stability of visual recourses of the landscape. Besides, all above mentioned infringements are considered to be dispersible and possessing no inclinations of concentration into nuclear.

The major part of infringements on the landscape is concentrated in the north-western part of the park where they act 6 times more intensively than in the other zones of infringement accumulation. The settlements of Dubingiai and Jurkiškis require a special notice, because rather great accumulations of infringements have been observed around. These sites are located near the highway Vilnius-Utena; however, Dubingiai is not only a rather densely populated territory, but also the main centre of attraction for visitors. The most common type of infringements is vividly seen in damage made for the forms of the terrain. Infringements, concerning forest usage and attendance, 


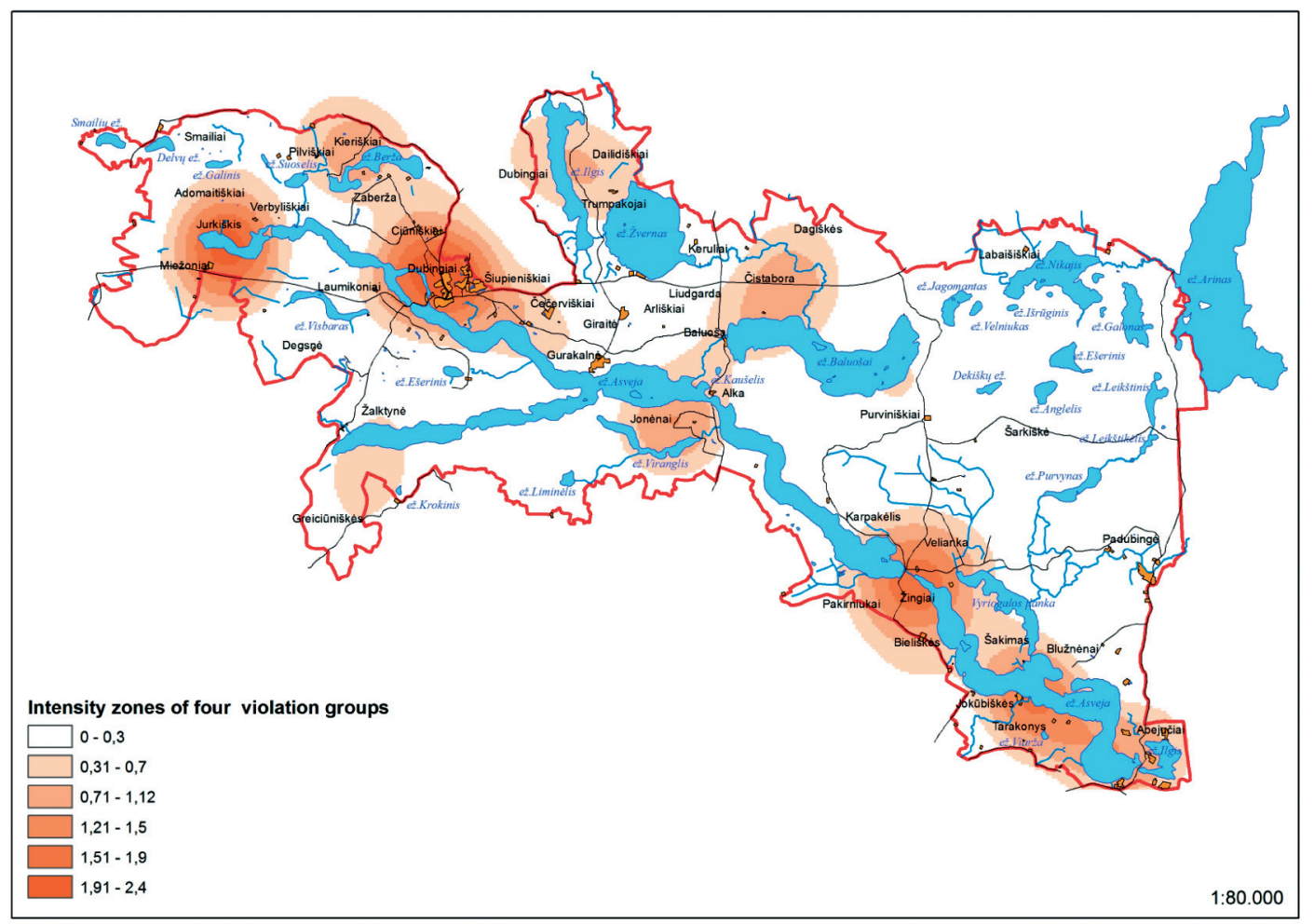

Fig. 2. Map of intensity zones of four violation groups (landscape, forests, constructional, water)

are registered at the southern shores of Asveja Lake. Practically, all infringements have been committed due to the illegal clearing of spaces and felling vegetation next to construction sites or future construction of buildings. The greatest accumulation of infringements on water areas and reservoirs are registered in the south-eastern part of Asveja at Abejučiai settlement where their concentration exceeds the indices of the accumulation of other infringements six times. The other zones accumulating infringements on Asveja Lake are getting narrower in the western part of the lake. Among the most frequently identified types of these infringements, violations in regulations on fishing are observed. The greatest part of violations in construction regulation have been registered in the northern and southern parts of the park at smaller villages and single household farms. The largest accumulation has been received at Bieliškiai and Kieriškiai villages that are nearly four times lower than the indices of the habitats located close at Čistabora and Trumpakojai villages. The most common type of these infringements is violating regional architectural regulations and requirements for the protected territories.

Vividly seen infringements, regarding park visitors and recreational activities of the park, have been registered in the non-recreational zones of the park: Šakymas nature reserve, the territories of reservations at Nikajos and Baluošai Lakes and Asveja Lake in the Žalktyne Lagoon that are mainly of the local character. The average scope of infringements has been registered not only at Baluošai Lake, but also in other places, and the scope of these violations is narrow. The locations analysed but not adapted and adjusted as recreational sites are considered as playground sites, their litter fall has been trampled down, and the sites used for fire places have been erected illegally.

The greatest threat to the visual resources of Asveja Regional Park was determined in the records for the period 2005-2010 that exhibited an intensified amount of constructional activities in progress; statistical data indicate an increasing number of visitors in the park. Taking into consideration the above mentioned circumstances, some public environmental protection movements have been initiated and targeted on the preservation of visual landscape resources (monitoring, strict inspection requirements, fines, educational upbringing) under the Governmental level. These activities have appeared to be rather efficient, because at present, the conditions and state of the majority of regular visual resources are sufficiently high. During the research period, only 82 infringements on requirements for landscape protection have been recorded. Activities are more consistent, related to the propagation of information on the tasks and goals of the 
protected territories as well on developing the consciousness of local people, those attending parks and the mutual cooperation of the related in-between institutions. At present, the state and conditions of the visual resources of the landscape have been estimated to be adequately high in Asveja Regional Park.

\section{Conclusions}

The investigated $\mathrm{NHO}$ and $\mathrm{CHO}$ are located unevenly, but the majority of them are found on the sites not accessible for visitors and not adapted for attendance. Therefore, most of the objects are not influenced by a greater impact of environmental and human economic activity. During the research study, the state and conditions of the objects of natural and cultural heritage have not undergone transformations, are relatively high and, in the nearest future, due to ongoing works on adapting objects to the needs of visitors, the situation has to be improved significantly. The research study has registered recreational infringements that comprise the greatest part of violations (40\%), whereas forest usage and attendance violations (5\%) make the least part. The percentage expression is equal among infringements on water areas and reservoirs (17\%). Violations in constructional regulations comprise $12 \%$ and landscape infringements make $26 \%$. The greatest part of infringements have been registered among violations in the variable visual recourses of the landscape recorded on three sites, i.e. western, south eastern and central areas of the park territory. Infringements bearing a low monetary value for fines reach $54 \%$ from the total number of all groups, the average fine value makes $33 \%$ and a higher monetary fine value is $13 \%$. The landscape of Asveja Regional Park is quite regular; while preserving its own visual potential, the largest threat to the park was in 2005-2010 caused by the scope of an increasing urbanization impact as well as by the intensified recreational possibilities.

\section{References}

Antrop, M. 1988. Invisible connectivity in rural landscapes, in K. F. Schreiber (Ed.). Proceedings of the Second International Seminar of IALE, Connectivity in Landscape Ecology, Münsterische Geographische Arbeiten, Münster, 29: 57-62.

Beconytė, G.; Kryžanauskas, A. 2010. Geographic communication for sustainable decisions, Technological and Economic Development of Economy 16: 603-612. http://dx.doi.org/10.3846/tede.2010.37
Clark, P. J.; Evans, F. C. 1954. Distance to nearest neighbour as a measure of spatial relationships in populations, Ecology 35: 445-453. http://dx.doi.org/10.2307/1931034

DRL. 2005. Lietuvos Respublikos Vyriausybès nutarimas. Dèl valstybinès aplinkos monitoringo 2005-2010 metu programos patvirtinimo [Decision of the Republic of Lithuania. Concerning the approval of the State Environmental Monitoring Program for 2005-2010], no. 130 from 7th of February, 2005 [online]. Available from Internet: http://www3.lrs. lt/pls/inter3/dokpaieska.showdoc_l?p_id=326805

Laukaityte, L. 2009. Lankytoju poveikio Nemuno kilpu regioninio parko gamtinei aplinkai vertinimas [Assessment of visitor impact on the Nemunas Loops Regional Park natural environment]: MSc Thesis. Vytautas Magnus University, Kaunas, Lithuania.

LRL. 1993. Lietuvos Respublikos saugomu teritoriju istatymas [Law of the Republic of Lithuania on Preserved Territories], no. I-301 from 9th of November, 1993 [online]. Available from Internet: http://www3.lrs.lt/pls/inter3/dokpaieska. showdoc_l?p_id $=441529$

Pileckas, M. 2004. Aplinkosauginių indikatorių taikymas Lietuvos kraštovaizdžio monitoringui: būklè, problemos, perspektyvos [The environmental indices usage for the monitoring of Lithuanian landscape; state, problems, perspectives], The geography year book 37: 112-123.

Sevenant, M.; Antrop, M. 2007. Settlement models, land use and visibility in rural landscapes: two case studies in Greece. Landscape and Urban Planning 80: 362-374. http://dx.doi.org/10.1016/j.landurbplan.2006.09.004

Silverman, B. W. 1998. Density estimation for statistics and data analysis. USA: Chapman \& Hall/CRC. 175 p.

Žinios. 1992. Lietuvos Respublikos Aukščiausiosios Tarybos nutarimas. Dèl regioninių parkų ir draustinių ịsteigimo [Resolution of the Supreme Council of the Republic of Lithuania or Restitution Seimas On the Establishment of Regional Parks and Reservations] no. I-2913 from 24 September, 1992 [online]. Available from Internet: http://www3.lrs.lt/ pls/inter3/dokpaieska.showdoc_l?p_id=1726\&p_tr2 $=2$

Jelena VAITKEVIČIENĖ. Assoc. Prof., Dr National Center of Remote Sensing and Geoinformatics "GIS-Centras", Sèlių g. 66, LT-08109 Vilnius, Lithuania. Ph +370 5273 1058, Fax.: +370 5 272 7723, e-mail: j.vaitkeviciene@gis-centras.lt.

Research interests: cartography and cartosemiotics, geographic information systems for optimization of methodology, special purpose mapping and analysis.

Aušra KUMETAITIENE். Assoc. Prof., Dr at the Department of Geodesy and Cadastre, Faculty of Environmental Engineering, Vilnius Gediminas Technical University Saulètekio al. 11, Vilnius, Lithuania. Ph +370 5274 4703, Fax +370 5274 4705, e-mail:ausra.kumetaitiene@sumin.lt.

Research interests: digital photogrammetric mapping, image interpretation, GIS methods, digital terrain models, digital terrain modelling parameters, regression models, multiple analysis. 